\title{
Comment on "What is the Value of an Archaeology Degree?"
}

\author{
Jim Grant \\ Assistant Principal \\ Cirencester College
}

My initial feeling on addressing this is guilt. I teach A Level Archaeology and over the past decade have seen $30-50 \%$ of those students annually going on to university to study archaeology. This proportion is unusual. Most students take at least three A Levels and a good proportion of those students go on to take completely new subjects at Higher Education (HE). I think this is a testimony to a genuine commitment to archaeology which predates their arrival at our College. Despite this and their desire to become archaeologists their post-degree destinations reflect fairly closely the general picture outlined in the lead article. Over the medium term, the picture is bleaker with many of those who have joined the profession dropping out after a few years; a pattern which may not be picked up in HE destination analysis. This is particularly the case with those from the less well-heeled section of the middle class and those who did not come from a family with university traditions. Ultimately many of my ex-students are disappointed and have to re-launch themselves whilst working in supermarkets. Of course this happens with students with other degrees but it does seem to particularly apply to archaeology.

One conclusion might be that archaeology degrees are a poor preparation for work. I have certainly heard professional archaeologists bemoan the lack of real digging experience of graduates but even if that were the case it would not explain the relative lack of success of archaeology graduates in getting other jobs. When students come back to visit after graduating I do not see any deficiency amongst the archaeologists relative to historians, psychologists, geographers etc. They all have $2: 1 \mathrm{~s}$, they have all matured and can all speak enthusiastically about particular elements of their studies. The one thing that stands out is the high proportion who wanted to be archaeologists, a phenomenon not replicated amongst the other humanities or sciences. The only areas where you see similar proportions with such subject-focused ambitions are Information Technology (IT), Physical Education, Art and Drama. What is particularly interesting is when you ask those A Level Archaeology students who did not go on to study it at HE why, they often reply that they did not want to be archaeologists. It is perceived as a vocational route unlike most other subjects.

I can only agree with the lead paper about why so many do not make it as archaeologists. The ability to ride out long periods of casual or voluntary work requires wealthy parents or huge determination and 'connections' sadly are still significant. Archaeology will continue to lose talent until a better paid or at least more reliable employment structure develops.

Papers from the Institute of Archaeology 17 (2006): 13-15 
As to why such a high proportion of students (and archaeologists) are white and middle class there are a variety of reasons. John Bishop's statement about archaeology not being the training for field archaeologists may be true. However, in the 1970s many graduates of other disciplines entered archaeology because there was a route through digging. Today virtually all new field archaeologists have an archaeology degree. Despite the valiant efforts of some local societies, the magazine Current Archaeology and some projects in urban areas, it is very difficult for members of the public to get involved in real archaeology. Archaeology will carry on being white and middle class until those at the top of the archaeological profession find ways to involve the public actively. While commercial units sometimes have to exclude amateurs because of their contracts or the whim of the county planning officer, university training digs do not. The latent interest is evident from the popularity of archaeological television, which has genuinely crossed at least the class barrier.

Archaeology also could do far more to help raise its profile in the school (and yes chaps I mean state schools) sector. The opportunity to study archaeology at school or college is very limited and highly regionalised. There are more centres offering it in the South West than in all the towns and cities of the Midlands for example. Archaeology as a discipline has also missed several tricks in the development of vocational education which might have broadened its base. For example, there is no archaeology element in the new BTEC (Building and Technology Education Council) First Diplomas for Countryside and Environment or Construction. There are significant opportunities for Archaeology in the new 14-19 Specialised Diplomas which will be introduced from 2008 but the time to exploit them is ticking away.

Returning to the issue of archaeology degree courses, I believe that perceived vocationalism is the main problem. It seems unreasonable to expect a degree course to turn out professionals particularly when one considers the breadth of archaeological work they could go into. In most other disciplines there is a period of vocational training before students are considered the finished article. Equally, if archaeology is not just for turning out archaeologists it presumably is doing no different from history, English, politics etc. It is turning out graduates with transferable skills. What is different is that students and prospective employers do not seem to see this. Archaeology is simply not valued as highly, as say history, in this respect. Employers do not know about the analytical skills involved and students do not value highly enough the breadth of their own studies.

More could be done by HE to identify the skills archaeology students acquire and to get that message through to both employers and students. I do not mean the deadly, reductionist taxonomies favoured by some lead bodies but the general transferable skills and the ability to acquire knowledge quickly which should be the hallmark of any good graduate. In other words, marketing it as a good degree which might add some grasp of science, technology or statistics to the virtues of the humanities. Colleagues have also stressed the experience some archaeology students have of project management and team leading on their excavation placements for example. Without distorting the subject too much, archaeology could probably offer more development of IT skills. 
At A level we say to students that it does not really matter what they choose. What matters is that they acquire skills and get high UCAS (Universities and Colleges Admissions Service) scores. They are most likely to do that following a course they enjoy. To some extent the same is true of degree courses. Publicising case studies of archaeology students who have gone on to successful non-archaeological careers might be a good first step. 